\title{
Are there wages from "sin"? Working conditions spillover from paying bribe in Vietnam
}

\author{
Uchenna EFOBI (D) Xuan VINH VO • Emmanuel ORKOH
}

Accepted: 6 April 2021 / Published online: 1 May 2021

(C) The Author(s), under exclusive licence to Springer Science+Business Media, LLC, part of Springer Nature 2021

\begin{abstract}
This paper examines how bribe payment by enterprises in Vietnam affects employees' working conditions, particularly wage benefits and other nonmonetary compensations. We exploit the variation in the interaction of the score for the transparency of the local government in a specific province, the districtsector share of enterprises engaging in bribe payment, and the sector average size of the enterprise owner's social network that are public officers as an exogenous variation in the likelihood of engaging in bribe payment. The results of the analysis reveal that when an enterprise pays bribe, it reduces the wages of its employees by approximately $27.6 \%$ (mostly for those within the highest wage bracket). Employees' membership of a trade union, enterprise' performance, capacity for inter-jurisdictional mobility, investment in human
\end{abstract}

\author{
U. EFOBI $(\bowtie)$ \\ Independent Researcher, Lagos, Nigeria \\ e-mail: ucefobi@gmail.com \\ U. EFOBI $\cdot$ X. V. VO \\ Institute of Business Research, University of Economics Ho Chi \\ Minh City, Ho Chi Minh City, Vietnam
}

X. V. VO

e-mail: vinhvx@ueh.edu.vn

\section{E. ORKOH}

Trade Research Focus Entity, Faculty of Economic and Management Sciences, North-West University, Potchefstroom, South Africa

e-mail: aorkoh@gmail.com capital development, and formality status are likely operative channels of impact.

Plain English Summary Enterprises' engagement in bribe payment has negative impacts on the wages of employees. Corruption and bribe payment are endemic in many developing countries and they come at a cost to the broader society. Several studies have been conducted on how corruption impacts the welfare of individuals and households, the productivity, and effective and efficient functioning of firms and government, but we contribute to this debate by considering how bribe payment at the firm level affects employees' welfare. We argue that bribe payment by an enterprise has potential effects on the wages and other non-monetary compensations of their employees. Depending on the size of the bribe and the profit level of the enterprise, bribe payment may reduce or improve an enterprises' cash flow. In an event that the enterprise incurs a cost for paying bribe, it may transfer the cost to its employees by either cutting their wages or adjusting other pecuniary benefits that they receive. On the other hand, if the enterprise benefits from paying bribe, employees' wages and other benefits could either increase as a spillover effect or remain unchanged depending on several factors, including the enterprise's appetite for further bribe payment in anticipation of reaping more benefits in the long term. We use a unique dataset from the survey of Vietnamese small- and medium-scale manufacturing enterprises to validate these propositions and the channels through which they operate. The results 
of the analysis show that when an enterprise pays bribe, it reduces the wages of its employees (mostly for those within the highest wage bracket) by approximately $27.6 \%$. Our result further shows that employees' membership of a trade union, an enterprise's performance and its capacity to move between different jurisdictions of operation, investment in human capital development, and formality status are the potential channels through which the identified impact operates. These findings support the need for anti-corruption policies, which could have other spillover effects on decent labor outcomes in Vietnam and other developing countries.

Keywords Bribe payment - Corruption · Employees working condition $\cdot$ Fringe benefits $\cdot$ Small and medium enterprise

JEL classifications $\mathrm{J} 81 \cdot \mathrm{J} 83 \cdot \mathrm{J} 88 \cdot \mathrm{K} 42 \cdot \mathrm{L} 26$

\section{Introduction}

There has been extensive literature on the deleterious effect of corruption on economic growth and development (Mendez and Sepulveda 2006). Other evolving studies have drawn mixed conclusions on the relationship between enterprise-level corruption and performance (Șeker and Yang 2014; Lavallee and Roubaud 2018). However, studies on the spillover effect of enterprise- level corruption on the welfare of employees remain limited. The few available studies on this policy issue have emphasized the macro effect of corruption on labor market outcomes and emigration of skilled workers (Schneider 2015; Cooray and Dzhumashev 2018), the relationship between corruption and salary in foreign-owned enterprises (Cole and Tran 2011), workers' protest as a result of managerial corruption (Chen 2000), reduction in public sector wages (Van Rijckeghem and Weder 1997), misallocation in hiring due to corruption (Weaver 2016), and determinants and evolution of firm-level corruption (Rand and Tarp 2012). This study contributes to this debate by considering the effect of enterprises' bribe payment on the wages and other non-monetary entitlements of employees from a developing country's perspective.

Tackling bureaucratic corruption and bribe payment has remained a public policy issue for developing countries. Some of these countries have initiated policies to address the abuse of power and corruption by public officials. For instance, in Vietnam, which is the country of this study's focus, the government has introduced several policy initiatives and set up institutions to address corruption, such as the 2005 anti-corruption law, which was amended in 2012. Several anti-corruption agencies such as the Office of the Central Steering Committee for Anti-Corruption, the Government Inspectorate, and the State Audit Office of Vietnam have also been set up to address public sector corruption. However, the country has not made much progress in achieving corruption reduction. This slow progress is evident by the country's low score (33 of 100) of the corruption perception index for 2018 and its placement among the two-third category globally, scoring below 50 in the corruption index (Transparency International 2020).

The ineffectiveness of the various initiatives to tackle corruption in Vietnam is due to the large implementation gap and lack of enforcement of regulations and laws by public officials (Martini 2012). Corruption in the country is mostly perpetrated by public officers, including traffic police, land cadres, customs officers, and tax authorities (Bai et al. 2017). These officials engage enterprises to pay a bribe to facilitate the execution of their basic tasks or services. However, monitoring these officers and their respective offices is difficult because corruption in Vietnam is mostly subnational, such that most business interactions, including business registration and other regulatory obligations, take place within public offices at the provincial level (Bai et al. 2017). The distribution of the line of authority and the distance between the capital city and the provincial offices further make it difficult to monitor the heads of the offices at the provincial level. Such a monitoring gap allows the provincial government's leadership, who has powers over their subordinate departments, district, and commune, to fix bribe for enterprises that contravene business regulations depending on the enterprises' performance (Tran et al. 2009).

This study, therefore, relies on an enterprise-level data across the ten provinces in Vietnam for the periods 2011, 2013, and 2015, to answer the following broad questions: (a) How does bribe payment affect the wages and other fringe benefits of the workers in the bribe-paying enterprises? (b) What are the potential mechanisms that explain the estimated relationships? To address the endogeneity issues with bribe payment, we exploit the variation in the interaction of the score for the transparency of the local government in a specific province, the district-sector share of enterprises engaging in bribe payment, and the sector 
average size of the enterprise owner's social network that are public officers as an exogenous variation in the likelihood of enterprises engaging in bribe payment. The results of the analysis show the following. First, bribe payment has a consistently negative and significant effect on workers' wages and wages to total value addition, mostly for workers within the highest wage bracket. Second, bribe payment does not significantly explain workers' nonmonetary entitlements, including having a formal contract, health insurance, annual leave, and sick leave. Third, the negative effects of bribe payment on workers' wages are mostly driven by non-union membership status of workers, and enterprises' low performance and capacity for inter-jurisdictional mobility, non-investment in human capital development, and formality status.

Apart from our contribution to the literature, addressing these policy-relevant questions is necessary for the debate about the attainment of the sustainable development goal 8 , which seeks to promote inclusive and sustainable economic growth, employment, and decent work for all by 2030 (International Labor Organization 2020). Specifically, we emphasize the consequences of corruption on workers' labor outcomes, including those monetary and non-monetary entitlements, which are directly linked to decent work. The remainder of the paper is structured as follows. Section 2 presents the analytical framework, while Section 3 describes the data and the empirical strategy. Section 4 illustrates the empirical results. Section 5 concludes the paper.

\section{Analytical framework}

The central argument of this study is that corruption significantly affects employees' working conditions. This proposition can be situated within the "grease the wheels" or "sand the wheels" frameworks. Proponents of the "grease the wheels" framework argue that corruption could improve business opportunities and performance by reducing the burden from bureaucracy and red tapes that could negatively affect enterprises' operations (Dutta and Sobel 2016; Williams et al. 2017; Lavallee and Roubaud 2018). This framework has been validated by studies including Vial and Hanoteau (2010) in Indonesia, Mendoza et al. (2015) in the Philippines, and Lavallee and Roubaud (2018) in the informal sector of selected West African countries. Williams and Kedir (2016) further find that corruption significantly enhances enterprises' annual sales, employment, and productivity growth rates in Vietnam.
The "sand the wheel" framework, on the other hand, suggests that bribe payments by an enterprise are additional costs to doing business, which may negatively affect growth and performance. For example, Fisman and Svensson (2007) and Şeker and Yang (2014) found a negative impact of corruption on businesses' sales growth in Uganda and Latin American and Caribbean region. Other studies (e.g., O'Toole and Tarp 2014; Paunov 2016) posit that corruption negatively impacts investment and the extent of small enterprise's innovation.

As illustrated in Fig. 1, irrespective of the nature (positive or negative) of the effect of corruption on enterprise's innovation, growth, performance, and productivity, there is a likelihood of its indirect spillover effects on monetary and non-monetary labor compensations (Fisman and Svensson 2007; Şeker and Yang 2014; O'Toole and Tarp 2014; Paunov 2016). In the event that an enterprise's payment of bribe negatively affects its financial performance, it transfers the cost of the bribe to its employees by either cutting their wages or adjusting other pecuniary benefits that they receive. In essence, as rational economic agents, enterprises are likely to offset the cost of paying bribe (i.e., low productivity and performance) by adjusting their labor costs (Coyne et al. 2010). As McKenzie (2017) highlighted, adjustments to enterprise' labor are a significant indicator of a struggling business.

When an enterprise benefits from paying bribes, employees' wages and other benefits could either increase as a spillover effect or remain unchanged depending on several factors, including the enterprise's appetite for further bribe payment in anticipation of reaping benefits in the long term. The literature (particularly those that show a positive correlation between corruption and some labor market outcomes such as employment growth) suggests that such practices might guarantee the going concern of an enterprise and employment expansion (Williams et al. 2017). Therefore, holding other factors, such as labor union activities constant, we argue that enterprises' engagement in corruption will have direct (positive or negative) effect on their performance, which in turn affects the working conditions of their employees. ${ }^{1}$

Corruption can also affect employees' working conditions, including their rights, privileges, and monetary outcomes, through enterprises' subversion of labor

\footnotetext{
${ }^{1}$ We explored other mechanisms through which corruption can affect employees' working conditions in the analysis.
} 


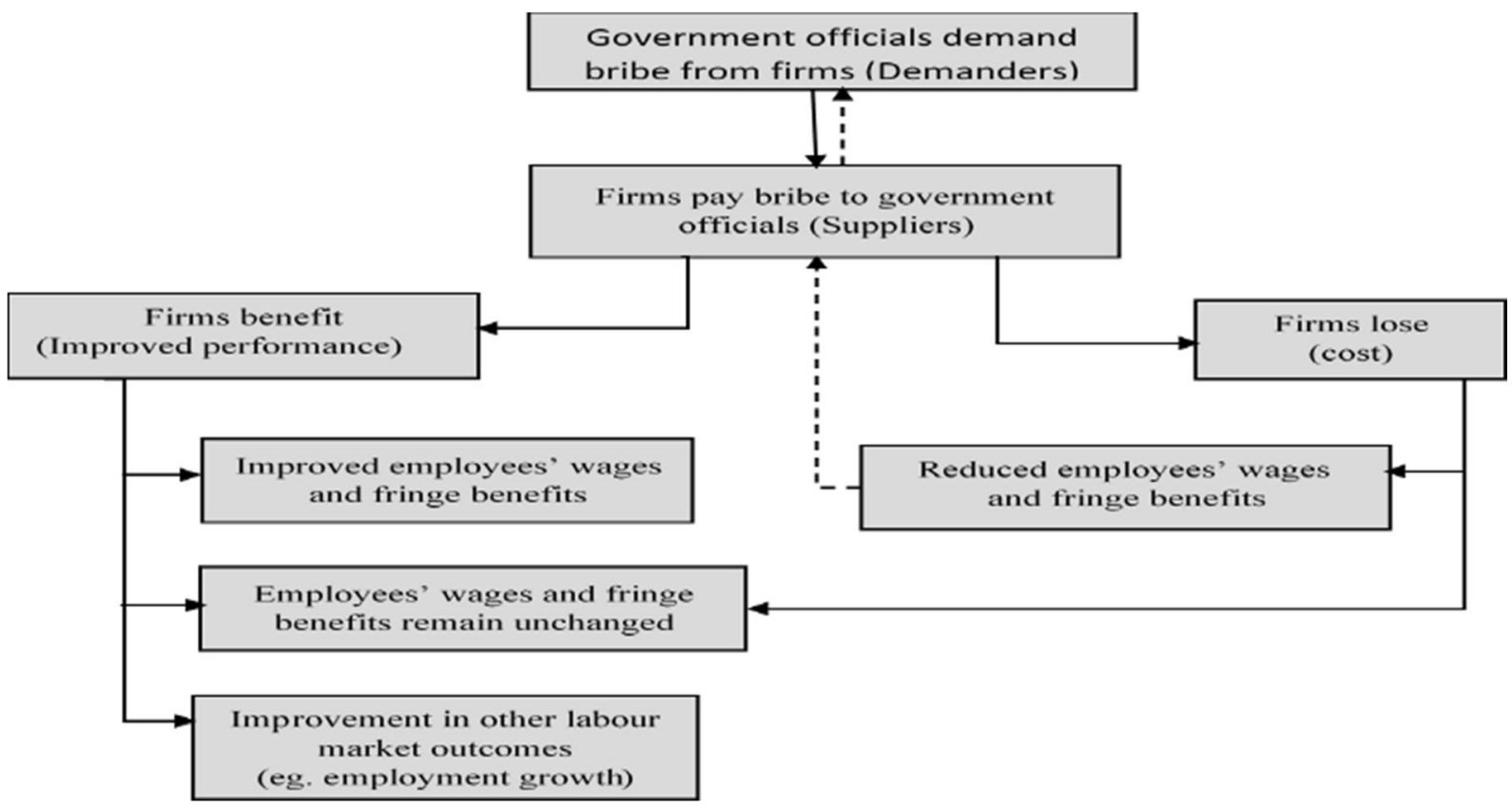

Fig. 1 A Framework of bribe payment and employees' welfare. Source: Authors

regulatory scrutiny and oversight (Dutta and Sobel 2016; Bai et al. 2017). This issue is prevalent in most developing countries where some government officials implicitly encourage regulation subversion by creating more regulatory obstacles to induce bribe payment (Banerjee 1997; Sylwester 2019; Rand and Tarp 2012). In such a setting, regulation may not be sufficient to ensure better working conditions for employees, since enterprises can easily bribe their way through rather complying with regulatory guidelines.

\section{Data and empirical strategy}

\subsection{Vietnamese small business survey}

This study relies on a unique dataset from the survey of Vietnamese small- and medium-scale manufacturing enterprises. The survey which covers the 10 provinces (Hanoi, Hai Phong, Ho Chi Minh City, Ha Tay, Phu Tho, Nghe An, Quang Nam, Khanh Hoa, Lam Dong, and Long An) of the country was collected by a collaborative effort of different agencies, including the Central Institute for Economic Management (CIEM) Vietnam, the Institute of Labour Science and Social Affairs (ILSSA) Vietnam, the Development Economics Research Group (DERG) at the University of Copenhagen, and the United Nations University - World Institute for Development Economics Research (UNU-WIDER).

Although previous rounds of the survey have been conducted in 2005, 2007, and 2009, this paper relies on the data from 2011, 2013, and 2015 rounds because they are the only publicly available rounds with comprehensive metadata on the labeling and coding of the variables. The limited information about the descriptions of the variables in the earlier rounds makes it difficult for their inclusion as a pooled data for the analysis. The sample frame includes only formal enterprises randomly selected from a merged population list from the 2002 General Statistics Office establishment census and the industrial survey for the period 2002-2005 (Rand and Tarp 2007). The selected sample businesses in the survey make up 30\% of all manufacturing enterprises in Vietnam as of the year of the establishment of the sample frame (Rand and Tarp 2007). Trifkovic (2017) describes other methodological steps taken for the selection of the sample. The participants of the survey are the owners of the enterprises, but in instances where they are not available for the interview, the enumerators interviewed the managers or any other individual in active control.

There are three components of the survey-enterprise, employee, and general economic perception. This study relies on only the enterprise and employee survey modules to achieve its objective. The enterprise survey includes information regarding the history of the enterprise, its ownership characteristics, production and sales 
structure, investments, fees, employment, environmental engagement structure, among others. The employee survey, on the other hand, randomly selects permanent full-time employees (between one and seven) that work in the surveyed enterprises. It includes information on their general characteristics, experience, remuneration and other benefits, labor contracts, among others. Each employee or enterprise was assigned a unique identifier, which we rely on to match each employee in the survey to the corresponding enterprise. The observations for the variables of the matched data are displayed in Table 1.

\subsubsection{Measuring bribe payment}

In the survey dataset, each small business owner/ manager was asked whether the enterprise paid a bribe to government officials. Other questions from the survey instrument include how much such payment is worth in Vietnamese Dong, and the purpose of the payment. Further, to understand the perception of these individuals regarding the level of corruption in society, they were asked whether they think that bribe payments would increase in the coming years. The survey instrument was carefully worded such that the questions on bribe and corruption were replaced with informal or communication fees to minimize the risk of underreporting actual involvement in corrupt practices.

Our study explicitly measures the experience of bribe by relying on the question whether the enterprise paid a bribe to government officials. This measure is the actual corruption experience at the enterprise level, rather than the perception of corruption (Lavallee and Roubaud 2018). The other measure of bribe payment (the amount of bribe paid by the enterprise in Vietnamese Dong) is underreported in the dataset; however, this additional variable was considered for robustness check, in a subsequent section.

From the survey, $54 \%$ of the enterprises paid a bribe in 2011, while in 2013 and 2015, 62.5\% and 56.3\% of enterprises paid a bribe. Overall, $57.8 \%$ of the enterprises in the entire period paid a bribe. The average amounts of bribe payment, which will be considered as a supplementary measure in the robustness check, were 7745.93 VND in 2011, 10,675.34 VND in 2013, and 16,756.27 VND in 2015. On average, the sampled enterprises had a total bribe payment of $19,769.38$ VND. The trend suggests that the size of bribe paid by the enterprises have increased over the years, which is consistent with the findings in Bai et al. (2017) that the amount of corruption remains substantial in Vietnam.

\subsubsection{Measuring the working conditions of workers}

We measure workers' working conditions as the average nominal monthly worker wage of the sampled employees, which was 2815.58 VND in 2011, and slightly declined to 2757.12 VND in 2015. However, the overall average value of this indicator is $2646.73 \mathrm{VND}$. We further consider the total wage compensation of employees relative to total value added by the enterprise to understand wage compensation as a share of value added by the bribe-paying engagement of the enterprise. The other supplementary measures, which we classify as non-monetary benefits, include whether the worker has a formal contract, receiving health insurance, annual leave, and sick leave.

The definition and summary statistics of these supplementary variables across the sample years are presented in Table 1. For instance, in 2011, about $47 \%$ of employees of the sampled businesses had a formal contract, which consistently increased to about $50 \%$ in 2013 , and $54 \%$ in 2015 . Overall, $50 \%$ of the sampled workers have a formal contract. Regarding health insurance and annual paid sick leave, we also see an increasing rate across the year. Overall, about $42 \%$ of the sampled workers have health insurance, and $43 \%$ have sick leave. Regarding annual leave, $33 \%$ of the workers in 2011 have such; while in 2013 and 2015, 37\% and $48 \%$ have such. Overall, $39 \%$ of the sampled workers have annual leave.

\subsubsection{Measuring other covariates}

We carefully select the other covariates for this study. They include the characteristics of the workers and the enterprises (and those of the owner/manager). Regarding the characteristics of the workers, we consider age, experience, and education, which are essential human capital variables that determine the earnings of the respective worker (Trifkovic 2017). The worker's gender is another essential characteristic that describes the wage differences of workers in Vietnam (Liu 2004).

We also control for the characteristics of the small businesses, which were carefully selected to include those variables that are correlated with employees working conditions and bribe payment at the enterprise level (Rand and Tarp 2012; Trifkovic 2017; Lavallee and 


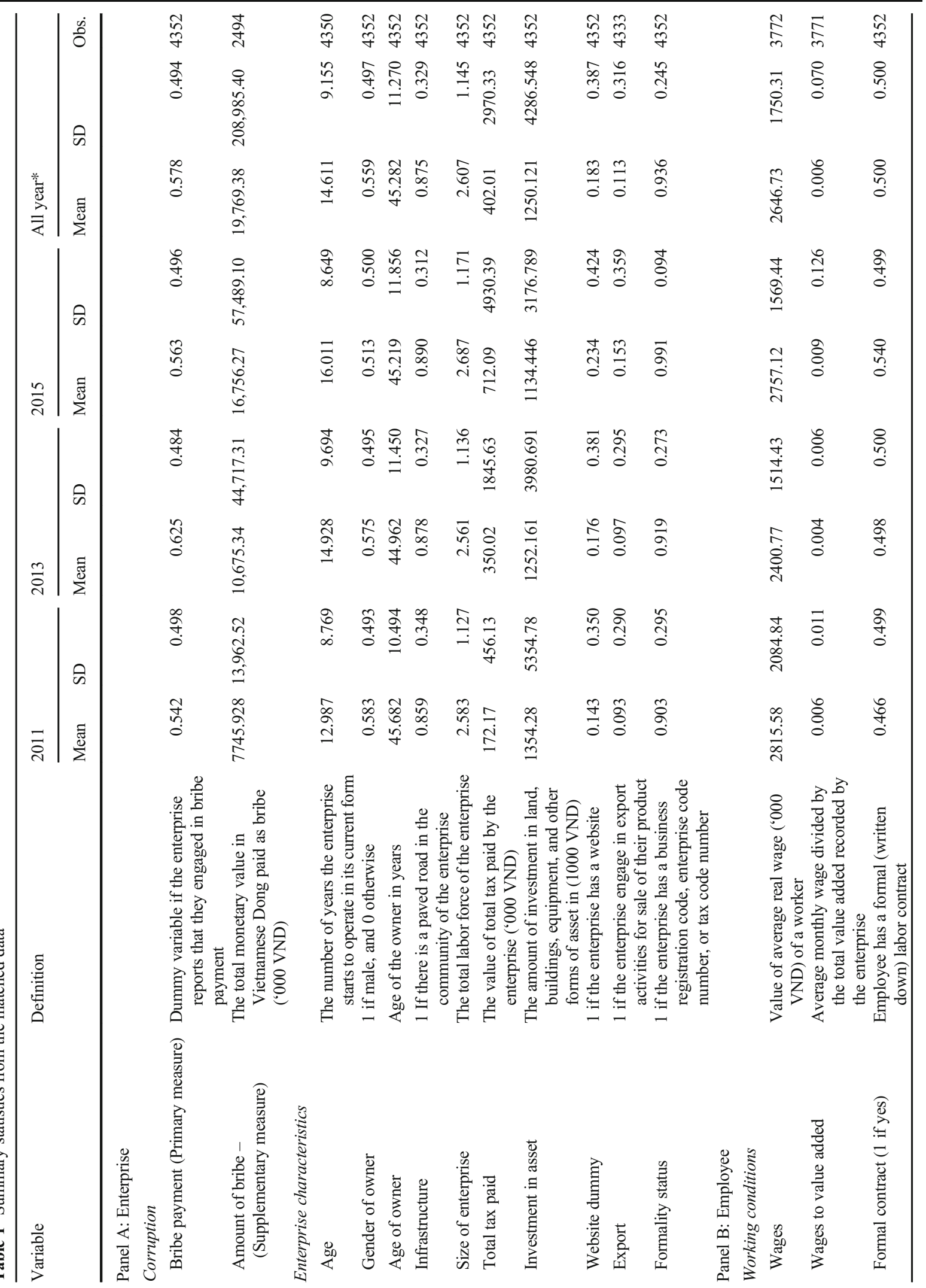




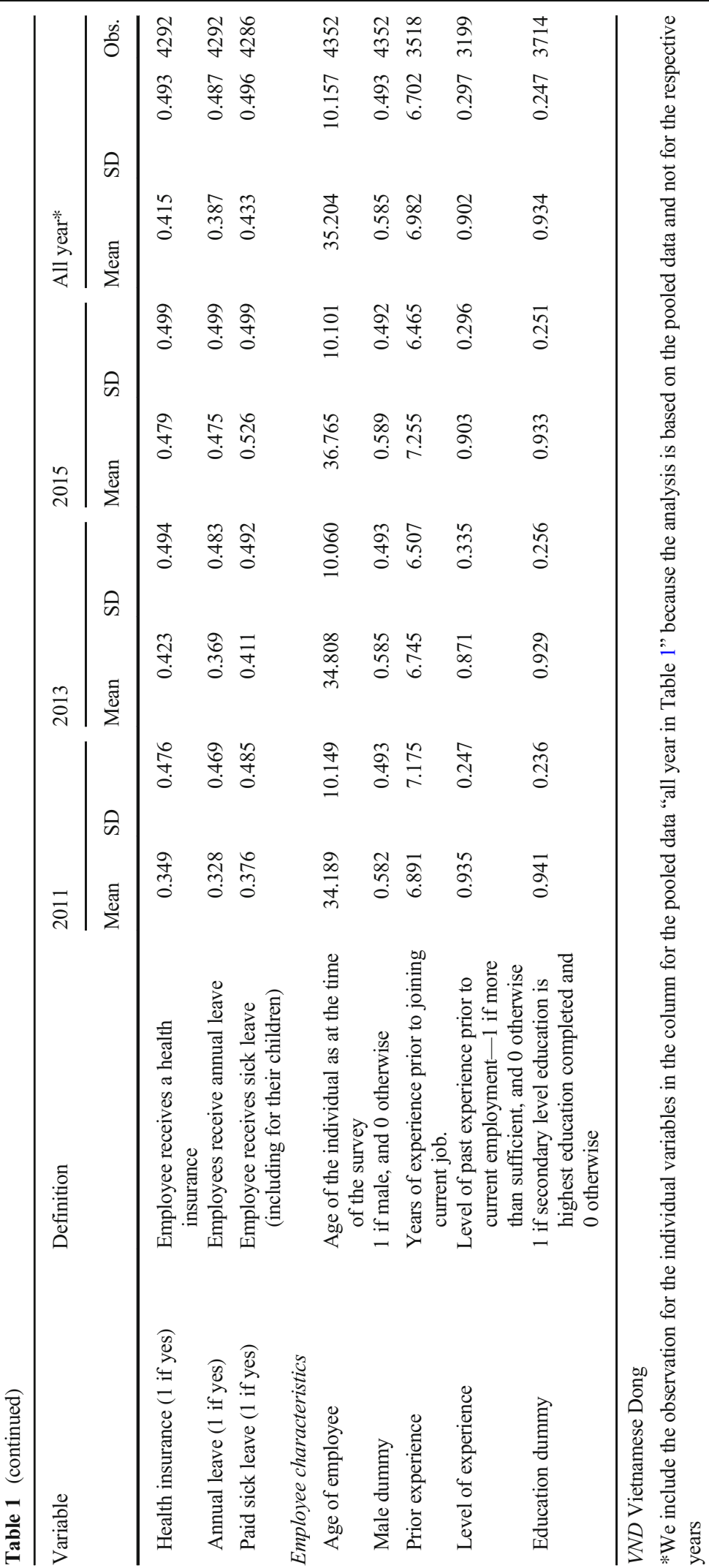


Roubaud 2018; Sylwester 2019). For instance, we control for the enterprises' age, size (total labor force), investment in assets, and total tax payment. We also include in the model the gender and age of the owner/ manager of these enterprises, and the presence of infrastructure in the community of operation of the enterprises. We also include the export status of the enterprise, as this reflects manufacturing capacity that could inform wages and exposure to demand for bribe (Lavallee and Roubaud 2018). Finally, we include the online presence and formality status of the enterprise. Table 1 further records the summary statistics and the definition of these covariates.

\subsection{Empirical strategy}

Equation (1) presents the basic specification, showing that the working conditions (WC) of worker " $i$ " in small business ' $b$ ' in sector ' $j$ ' in a particular province ' $p$ ' and time ' $t$ ' depends on bribe payment $(B p)$, and other covariates as earlier discussed:

$$
\begin{aligned}
W c_{i, b, j, p, t}= & \alpha+\beta B p_{b, j, p, t}+\lambda \chi_{i, b, j, p, t}+\beth_{i}+\delta_{b} \\
& +\mathfrak{J}_{j}+\rho_{p}+\tau_{t}+\varepsilon_{i, b, j, p, t}
\end{aligned}
$$

The usual enterprise and employee covariates are included in the model (1) as ' $\chi$ '. $\mathfrak{I}_{i}, \delta_{b}, \mathfrak{J}_{j}, \rho_{p}, \tau_{t}$ are the fixed effects at the worker-, enterprise, sector, location, and survey year levels. $\varepsilon_{i, b, j, p, t}$ is the error term, which we cluster at the district, sector, and province level. These fixed effects are considered in the empirical model to account for the unobservable differences at these five levels that could impact working conditions.

Although we estimate such naïve regressions (Eq. 1) for comparison, a key concern in establishing the effect of bribe payment on workers' compensation is the potential endogeneity of bribe payment. As inferred from the conceptual framework in Fig. 1, payment of bribe by enterprises is not entirely exogenous. It is influenced by several unobserved factors including the acceptance or otherwise of bribery as a convention by other business, the severity of punishment for enterprises that pay bribe and the public officials who engage in the act of corruption, enterprises' expectation regarding the effect of bribe payment on their performance and other institutional factors. There could also be a reverse causality in the model such that the enterprises pay bribe to circumvent labor regulations and regulatory scrutiny related to employment because of poor working conditions. Further, there could be some unobservable confounding variables that may be correlated with both bribe payment and working conditions. For example, there could be changes in informal institutions in the location where the enterprise is sited or even changes in internal policies of the enterprise that could result in changes in both attitudes towards bribe payment and working conditions of employees. Although not reported, the test for endogeneity of bribe payment suggests a rejection of the null hypothesis that the variable is exogenous at $1 \%$ level.

Addressing the endogeneity concerns require an identification strategy that relies on an instrument that is strongly correlated with bribe payment, but not directly associated with workers' wages. We rely on the instrument that is constructed by interacting the score for the transparency of the local government in a specific province, ${ }^{2}$ the district-sector share of enterprises engaging in bribe payment, and the sector average size of the owner's social network that are public officers. The values for the transparency of the local government in a specific province are obtained from the Vietnam Provincial Competitiveness Index (PCI). The index is computed by asking enterprises about the extent of transparency of planning documents, legal decisions and decrees, access to provincial materials, ease of negotiations with the tax authority, and openness of provincial webpage for relevant information (PCI 2020). For the analysis we subtracted $7.5^{3}$ from the index to create an inverse representation as 0 (most transparent) to 7.5 (less transparent).

Considering bribe payment as those actions that could be informed by activities of other enterprises in the industry and location of the enterprise (Fisman and Svensson 2007), we use the rate of bribe payment in the peer group of the sampled enterprises, defined over the geographical location (district), and business activity (sector) proximity. Further, the owner/manager's social networks can matter for the extent of bribe payment, as described in Lavallee and Roubaud (2018). That is, the number of social networks of the owners of the enterprise that are politicians and public officers, and which the respondent has been in touch with at least once every

\footnotetext{
2 This variable is recorded as higher values implying less openness/ transparency.

${ }^{3}$ We chose 7.5 because it is the maximum threshold for the initial PCI index.
} 
3 months, averaged for the peer group. This indicator could reflect the likelihood of exposure to bribery encounters. The interaction of these three variables characterizes the environment in which small businesses operate, capturing the potential for bribing. In essence, a small business in locations and sectors with higher bribe incidence, relatively more extensive contact with public officers, and in a province with low transparency, is likely to engage in bribe payment.

Having computed this instrument, the next issue is to ascertain its validity. That is, apart from being strongly correlated with the endogenous variable, the instrument can only affect workers' wages through bribe payment. This is the so-called exclusion restriction condition, which must be guaranteed, despite being difficult to verify. However, we provide some evidence that the instrument meets the excludability assumption.

There could be crucial spatial distribution and cluster influences on workers' wages, which may depend on a set of relatively immobile resources (such as knowledge) clustered in specific sectors or locations (Sorensen 2011; Verdu and Tierno 2019). Further, noting that corruption is subnational in Vietnam, small businesses could relocate their activities from high corrupt province to less corrupt areas (Bai et al. 2017), which could also affect wages due to relocation cost. Therefore, such instruments that are constructed at the location and sector level could likely pick up these other spatial and sectorial influences that could also affect wages. This threat, however, is highly unlikely considering that the relocation of sites depends on the financial capacity of the enterprise, which is likely for larger businesses compared to smaller businesses (Bai et al. 2017). Further, we control for the location and sector fixed effects, and we include an extensive set of covariates. Hence, it is unlikely that the chosen instrument directly affects workers' wages in a particular business, but may increase the chances of engaging in bribe.

In a mathematical form, therefore, the first-stage regression, which displays the relevance of the instrument, is defined in Eq. (2):

$$
\begin{aligned}
B p_{b, j, p, t}= & \alpha+\beta \text { Instrument }_{b, j, p, t}+\lambda \chi_{i, b, j, p, t}+\delta_{b} \\
& +\mathfrak{\Im}_{j}+\rho_{p}+\tau_{t}+\varepsilon_{i, b, j, p, t}
\end{aligned}
$$

where the instrument is earlier defined, while the covariates overlap with those in Eq. (1). The usual error term $\varepsilon_{i, b, j, p, t}$ captures the remaining variance of $B p_{b, j, p}, t$, which is not explained by the covariates and the instrument.
We also estimate the reduced form equation, which tests the null hypothesis that all coefficients related to the excluded instrument are simultaneously equal to zero.

$$
\begin{aligned}
W c_{i, b, j, p, t}= & \alpha+\text { Instrument }_{b, j, p, t}+\lambda \chi_{i, b, j, p, t}+\mathbf{\beth}_{i} \\
& +\delta_{b}+\mathfrak{J}_{j}+\rho_{p}+\tau_{t}+\varepsilon_{i, b, j, p, t}
\end{aligned}
$$

The second stage regression on the other hand, is estimated as shown in Eq. (4):

$$
\begin{aligned}
W c_{i, b, j, p, t}= & \alpha+\lambda \chi_{i, b, j, p, t}+\widehat{\gamma V}_{1}+\beth_{i}+\delta_{b}+\mathfrak{I}_{j} \\
& +\rho_{p}+\tau_{t}+\varepsilon_{i, b, j, p, t}
\end{aligned}
$$

Applying the instrument in the two-stage least squares $(2 s l s)$ regressions, the estimation of the effect of bribe payment on workers' wages corresponds to a local average treatment effect (LATE), which measures the effect of the instrument on those who engaged in bribe payment - i.e., compliers. Therefore, if the key IV assumption holds, any observed relationship between bribe payment and workers' outcomes has a causal interpretation for compliers (see Trifkovic 2017). We apply the linear IV estimation approach, which preserves the control function assumption (Angrist 2001).

Before getting into the discussions of the main results, it is important to note that as presented in the last column of Table 1 and the subsequent subsections, there were different observations for each variable after merging the employee data onto the enterprise level data. This together with the different estimation techniques employed in the analysis contributed to the reduction and variations in the sample sizes that are reported in the output tables in Section 4 (Empirical analysis) and at the Appendix.

\section{Empirical analysis}

\subsection{Bribe payment and workers' wages}

We begin the empirical analysis by first estimating the relationship between bribe payment and workers' wage outcome without addressing the endogeneity concerns. Columns (1) and (3) of panel A of Table 2 report the regression estimates that include all the covariates, while columns (2) and (4) are similar but control for the worker, enterprise, sector, location, and survey year fixed effects, while the standard errors are clustered at 
Table 2 Bribe payment and wages of workers

Panel A: Without considering the panel structure of the data

Log Wages

Bribe payment

Bribe payment

Employee characteristics Yes

Enterprise characteristics Yes

Observations

Hausman test (prob.)

Outcome mean

Model

\author{
Wages to \\ value added
}

(1) 2343

\section{Log Wages}

(5)

(4)

$-0.023 * * *$
$(0.007)$

7.645

OLS
(0.050)

Yes

2196

7.645

(3)

OLS
(0.004)

Yes

Yes

2342

(0.007)

Yes

Yes

2196

0.006

OLS
0.006

OLS

$-0.203 * * *$

(0.050)

Yes

Yes

2343

0.052

7.645

Fixed effect

Panel B: Considered the panel structure of the data

Wages to

value added

(6)

$-0.023 * * *$

(0.006)

Yes

Yes

2342

0.002

0.006

Fixed effect

Columns (1) and (3) control for the employee and enterprise's characteristics, while columns (2) and (4) control for the fixed effects at the province, year, sector, workers, and enterprise level, and the standard errors in parenthesis are clustered at the district, sector, and province level. The estimates in columns (5) and (6) are the fixed effect regression. The following characteristics of the employees are included in all the columns: age, male dummy, prior experience, level of experience, and education dummy (1 if secondary school). We also include the following enterprise characteristics as follows: age of the enterprise, gender and age of the owner/manager, infrastructure dummy, size of the enterprise (log), total tax paid $(\log )$, investment in asset $(\log )$, website dummy, export dummy, and formality status. $* *<0.05 ; * * *<0.01$

the district, sector, and province level. ${ }^{4}$ Taking advantage of the panel structure of the data, we also report the fixed effects regression results in columns (5)-(8).

The results from panels A and B generally indicate a negative relationship between bribe payment by enterprises and workers' wages. The estimates in columns (2) and (4) of panel A are the most extensive specification for the model that do not consider the panel structure of the data, suggesting that the wages of workers in enterprises that engage in bribe payment decreases by $12.2 \%$ and the ratio of wages to value addition of such workers also decreases by $2.3 \%$. Compared to the average wage of workers in the sample, an employee in an enterprise that pays bribe sees a $1.2 \%$ lower wage compensation and about 4 fold lower wage to value added ratio compared to those of workers in an enterprise that does not pay bribe. When considering the panel structure of the data in panel B, the Hausman test suggests that the fixed effect estimates are the most efficient, and the results from column (5) suggest that that the wages of an employee in an enterprise that pays bribe reduces by $20 \%$. This decline is $2.7 \%$ lower than the average wage compensation of the workers in the sample. Further, the estimate from column (6) suggests that a worker in an enterprise that pay bribe sees a $2.3 \%$ decline in their

\footnotetext{
$\overline{{ }^{4} \text { The instrument }}$ for the $2 s l s$ estimation is constructed at these levels.
}

wage to value addition of the enterprise, which is about 4 fold lower compared to the average wage to value addition of the sampled workers.

\subsubsection{Addressing the endogeneity concerns}

Recall that the estimates presented in Table 2 do not address the endogeneity concerns with the bribe payment variable, which we now consider in Table 3 . The estimates for the first- and second-stage regression in columns (1), (3), and (5) exploit the interaction between the score for the transparency of the local government in a specific province (rescored as higher values for less transparency), the district sector share of enterprises engaging in bribe payment, and the sector average size of the enterprise owner's social network that are public officers as an exogenous variation in bribe payment. The estimates of the reduced form equation are also presented in Table 3 in columns (2) and (4), which tests the null hypothesis that all coefficients related to the excluded instrument are simultaneously equal to zero.

We only focus on the estimates of the most extensive specification for concise discussion. The first-stage results in columns (1) of Table 3 suggest that the instrument has a significant and positive correlation with bribe payment. Implying that the interaction of the score for the extent of non-transparency of the local government 
Table 3 Bribe payment and wages of workers (2sls and reduced form estimates)

\begin{tabular}{|c|c|c|c|c|c|}
\hline & $\begin{array}{l}\text { Bribe payment } \\
\text { (1) }\end{array}$ & $\begin{array}{l}\text { Wages }(\log ) \\
\text { (2) }\end{array}$ & $\begin{array}{l}\text { Wages (log) } \\
\text { (3) }\end{array}$ & $\begin{array}{l}\text { Wages to } \\
\text { value added } \\
\text { (4) }\end{array}$ & $\begin{array}{l}\text { Wages to } \\
\text { value added } \\
\text { (5) }\end{array}$ \\
\hline Instrument & $\begin{array}{l}0.123 * * * \\
(0.006)\end{array}$ & $\begin{array}{l}-0.034^{* *} \\
(0.015)\end{array}$ & & $\begin{array}{l}-0.004 * * \\
(0.02)\end{array}$ & \\
\hline Bribe payment & & & $\begin{array}{l}-0.276^{* *} \\
(0.119)\end{array}$ & & $\begin{array}{l}-0.031 * * \\
(0.016)\end{array}$ \\
\hline Employee characteristics & Yes & Yes & Yes & Yes & Yes \\
\hline Enterprise characteristics & Yes & Yes & Yes & Yes & Yes \\
\hline Observations & 2196 & 2196 & 2196 & 2196 & 2196 \\
\hline First stage F-stat & 359.92 & & & & \\
\hline Outcome mean & 0.578 & 7.645 & 7.645 & 0.006 & 0.006 \\
\hline Model & IV 1st Stage & OLS & IV 2nd Stage & OLS & IV 2nd Stage \\
\hline
\end{tabular}

The dependent variables for each model are presented at the top of each column. Columns (1) and (4) are the estimates of the first-stage regression; columns (2) and (5) are the estimates for the reduced form model, while columns (3) and (6) are the estimates for the second-stage regression, which is the ratio of the estimates for the reduced form and the first stage. All the columns control for the fixed effects at the province, year, sector, workers, and enterprise level, and the standard errors in parenthesis are clustered at the district, sector, and province level. The following characteristics of the employees are included in all the columns: age, male dummy, prior experience, level of experience, and education dummy ( 1 if secondary school). We also include the following enterprise characteristics as follows: age of the enterprise, gender and age of the owner/manager, infrastructure dummy, size of the enterprise (log), total tax paid (log), investment in asset $(\log )$, website dummy, export dummy, and formality status. $* *<0.05 ; * * *<0.01$

in a specific province, the district sector share of enterprises engaging in bribe payment, and the sector average size of the enterprise owner's social network that are public officers has a positive and significant association with the likelihood of bribe payment. The first-stage Fstatistics that is higher than ten further shows that the instrument is valid and that the weak instrument problem is not a concern.

The estimates of the reduced form regression in columns (2) and (4) and the second-stage estimates in columns (3) and (5) in Table 3 show a decline in wages of workers in an enterprise that pays bribe. In particular, the second-stage estimate in column (3) reinforces the reduced form effect by showing that engaging in bribe payment by an enterprise results in $27.6 \%$ significant decline in the wages of employees. Relative to the average wage compensation of workers in the sample, this translates to a $3.6 \%$ decline. Likewise, the estimate in column (5) of Table 3 also suggests that there is a $3.1 \%$ significant decline in the ratio of an employee's wage to total value addition of the enterprise with bribe payment (i.e., a 5 fold decrease in wages relative to the mean).

The results presented in Table 3 confirm that there is a negative relationship between small business bribe payment and worker's wage compensation. The results further suggest that irrespective of the consistently negative and significant effect of bribe payment on wages in both the regression results in Table 2 and second-stage results of the $2 s l s$ specification in Table 3 , the estimates in Table 2 are upwardly biased ${ }^{5}$ but do not show any deviation from the earlier conclusions about the negative consequences of bribe payment on worker's monetary compensation.

We see from Tables 2 and 3 that overall, an enterprise's engagement in bribe payment has an adverse effect on its workers' wages. Although we later check for the likely operative channels of impact, the estimated negative relationship does not claim that corruption is detrimental to the overall labor market outcomes of workers, as some evidence also suggest that corruption positively correlates with employment growth (Williams et al. 2017). Therefore, this initial finding acknowledges the complexity of the effect of corruption on labor market outcomes, while showing that

\footnotetext{
$\overline{{ }^{5} \text { Such bias could }}$ arise from those time-varying changes in enterprise and employee unobservable characteristics that are correlated with both bribe payment and working conditions. For example, a change in management could lead an enterprise to both pursue policies that desist bribe payment and improve working conditions, in which case the regression estimates would not capture such issues.
} 
corruption is negatively related to changes in the reward/ remuneration that accrue to workers.

\subsubsection{Differential effect of bribe payment on workers' wages}

It is conceivable that enterprises' bribe payments are likely to have a differential impact on different wage earners. For example, bribe payments might have a disproportional effect on workers in the lower wageearning category relative to those at the median or upper wage-earning bracket of the wage distribution. The possibility of the presence of heterogeneous returns/slopes along the whole range of enterprise workers' wage distribution might therefore exist. We test the presence or otherwise of this heterogeneity and present the estimates of the quantile regression in Table 4.

The results show a non-monotonic relationship between bribe payment and wage distribution. At lower and middle wage bracket (25th and 50th percentile,) bribe payment by the enterprise has no significant effect on wages. However, the relationship is seen to be negative and significant in magnitude at the 90th percentile. We find similar higher negative and significant effect of bribe payment for those workers at the 90th percentile for wages to value addition compared to those at the 25 th and 50th percentile. We interpret the difference in the estimates of bribe payment across the wage percentile, which is only clearer for the ratio of wages to value addition. This suggests that the effects of enterprises' engagement in bribe payment on employees' wages are proportionate to the sizes of the wages. Thus workers in the higher wage-earning bracket loose earnings compared to the lowest or middle wage earners.

\subsection{Bribe payment and fringe benefits}

Noting that there is a negative relationship between bribe payment and the wages of workers in small businesses, the next issue is the consideration of the effect of bribe payment on other non-monetary outcome of workers. We consider four outcome variables, which provide information on whether the sampled worker has a formal contract, a health insurance, receive annual leave, and sick leave. The estimates for the fixed effect regression (including the estimate that takes advantage of the panel nature of the data) and the second stage of the $2 s l s$ regression are reported in Table 5. We only report the first-stage F-stat, but do not report the estimates for the first-stage regression and the reduced form model since they are not the focus of discussion. ${ }^{6}$

Columns (a) and (c), respectively, report the estimates for the OLS and the second-stage of the $2 s l s$ regression analysis that adjusts for the fixed effects at the province, year, sector, workers, and enterprise level, and clusters the standard errors at the district, sector, and province level. Column (b) reports the estimates for the fixed effect regression that takes advantage of the panel nature of the survey data, noting that the Hausman test rejects the null hypothesis that the unique errors in the model are not correlated with the regressors.

The estimates from panels A, B, C, and D illustrate that the effect of bribe payment on non-monetary benefits of workers is not reliably significant at the traditional one and $5 \%$ levels. For example, the estimates from panels $\mathrm{A}, \mathrm{B}, \mathrm{C}$, and $\mathrm{D}$ suggest that bribe payment does not significantly explain the likelihood of workers' having a formal contract, having a health insurance, been entitled to an annual paid leave, and entitled to a sick leave. This relationship is consistent for both OLS and $2 s l s$ regression analysis. However, the estimate in column (3b) was only significant for the likelihood of not receiving an annual leave with an enterprise bribe payment. Nonetheless, this estimate is not convincing, noting that the results from the OLS and the second-stage regression are not significant.

\subsection{Potential mechanisms}

The potential mechanism that explains the estimated relationship between bribe payments and monetary compensation are considered in this section as follows.

\subsubsection{Employee mobility and union membership}

First, we consider whether the employee mobility status and union membership determine the extent of the effect of bribe payment on workers' wages. We measure mobility status following Campbell et al.'s (2012) approach as a dummy if the employee's dominant employer changed since the previous year. That is, 1 if a worker has been employed in the current enterprise before the year of the survey, and 0 if they have not. Union membership, on the other hand, is a dummy variable, which takes the value 1 if the worker is a union member, and 0 otherwise. The estimations provide additional evidence

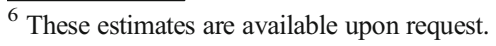


Table 4 Effect of bribe payment on wages of workers (quantile regression)

\begin{tabular}{|c|c|c|c|c|c|c|}
\hline & \multicolumn{3}{|l|}{ Wages (log) } & \multicolumn{3}{|c|}{ Wages to value added } \\
\hline & $\begin{array}{l}\text { 25th percentile } \\
\text { (1) }\end{array}$ & $\begin{array}{l}\text { 50th percentile } \\
\text { (2) }\end{array}$ & $\begin{array}{l}75 \text { th percentile } \\
\text { (3) }\end{array}$ & $\begin{array}{l}\text { 25th percentile } \\
\text { (4) }\end{array}$ & $\begin{array}{l}\text { 50th percentile } \\
\text { (5) }\end{array}$ & $\begin{array}{l}\text { 75th percentile } \\
\text { (6) }\end{array}$ \\
\hline Bribe payment & $\begin{array}{l}0.005 \\
(0.028)\end{array}$ & $\begin{array}{l}-0.019 \\
(0.021)\end{array}$ & $\begin{array}{l}-0.058 * * * \\
(0.021)\end{array}$ & $\begin{array}{l}-0.000^{*} \\
(0.000)\end{array}$ & $\begin{array}{l}-0.000 * * * \\
(0.000)\end{array}$ & $\begin{array}{l}-0.002 * * \\
(0.001)\end{array}$ \\
\hline Employee characteristics & Yes & Yes & Yes & Yes & Yes & Yes \\
\hline Enterprise characteristics & Yes & Yes & Yes & Yes & Yes & Yes \\
\hline Observations & 2343 & 2343 & 2343 & 2342 & 2342 & 2342 \\
\hline Outcome mean & 7.645 & 7.645 & 7.645 & 0.006 & 0.006 & 0.006 \\
\hline
\end{tabular}

The dependent variables for each model are presented at the top of each column. All the columns control for the following characteristics of the employees: age, male dummy, prior experience, level of experience, and education dummy (1 if secondary school). We also include the following enterprise characteristics as follows: age of the enterprise, gender and age of the owner/manager, infrastructure dummy, size of the enterprise $(\log )$, total tax paid $(\log )$, investment in asset $(\log )$, website dummy, export dummy, and formality status. $*<0.10 ; * *<0.05$; $* * *$ $<0.01$

that the effects of bribe payment indeed operate through the membership status of a worker in a trade union, but not through their mobility status. In essence, we show evidence in panel A of Table 6 that the adverse monetary compensation effect from bribe payment is stronger among workers who are not members of a trade union.

\subsubsection{Enterprise performance and mobility status}

Next, we consider the enterprises' performance and mobility status as important operating channels that explain the relationship between bribe payment and workers' wages. Literature indicates that corruption in developing countries could negatively affect the outcomes of small businesses (including labor cost and other overhead expenditures) through changes in performance (Bai et al. 2017; Lavallee and Roubaud 2018). Therefore, it is likely that the negative effect of paying bribes on workers of Vietnamese small businesses may only be seen depending on the performance of the enterprise. To check whether performance of the enterprise is at play, we interact bribe payment with the performance variable (total sales value) and the estimates are reported in panel B of Table 6 .

Other literature highlights that in countries where corruption are largely subnational and bribe rates are set at provincial government level — as it is the case in Vietnam - the impact of bribe on the outcome of businesses is relative to the enterprises' capacity for interjurisdictional mobility (Bai et al. 2017). For example, if some bribes are fixed fees (say inspectors demand bribe from offices they visit irrespective of the firm's size) in a specific province and some bribes in other provinces are a fixed proportion of revenue, the effect of bribe on outcomes of businesses would likely depend on the capacity for movement across locations (Bai et al. 2017). Enterprise with such capacity can negotiate their bribe rates because of the leverage they have to relocate their operations to other provinces that may likely request lower amount of bribe, and could matter for reducing the cost of corruption on the enterprise's operations (see Bai et al. 2017). We consider the proxy, whether the enterprise operates its manufacturing operations in multiple provinces, and we interact this variable with bribe payment (see panel B of Table 6).

The regression results in panel $\mathrm{B}$ suggest that bribe payment has a significant negative effect on the wages of workers in low performing enterprises, but not for those in high-performing enterprises. We also do not find any significant effect of bribe payment on the ratio of wages to value addition by the performance of the enterprise (see columns 3 and 4 of panel B). Further, we find from panel B that enterprises' mobility status is an important mechanism through which the effect of corruption on wages is seen. For example, a worker in an enterprise that pays bribe is likely to see over $30 \%$ increases in wages and over $3 \%$ increase in wages to value addition only if the enterprise operates in more than one location. These effects are significant at the 1 and 5\% levels. These effects indicate that despite the consistent negative effect of bribe payment on wages, workers in high-performing enterprises or enterprises that operate in more than a single location are more likely to see higher wages. 


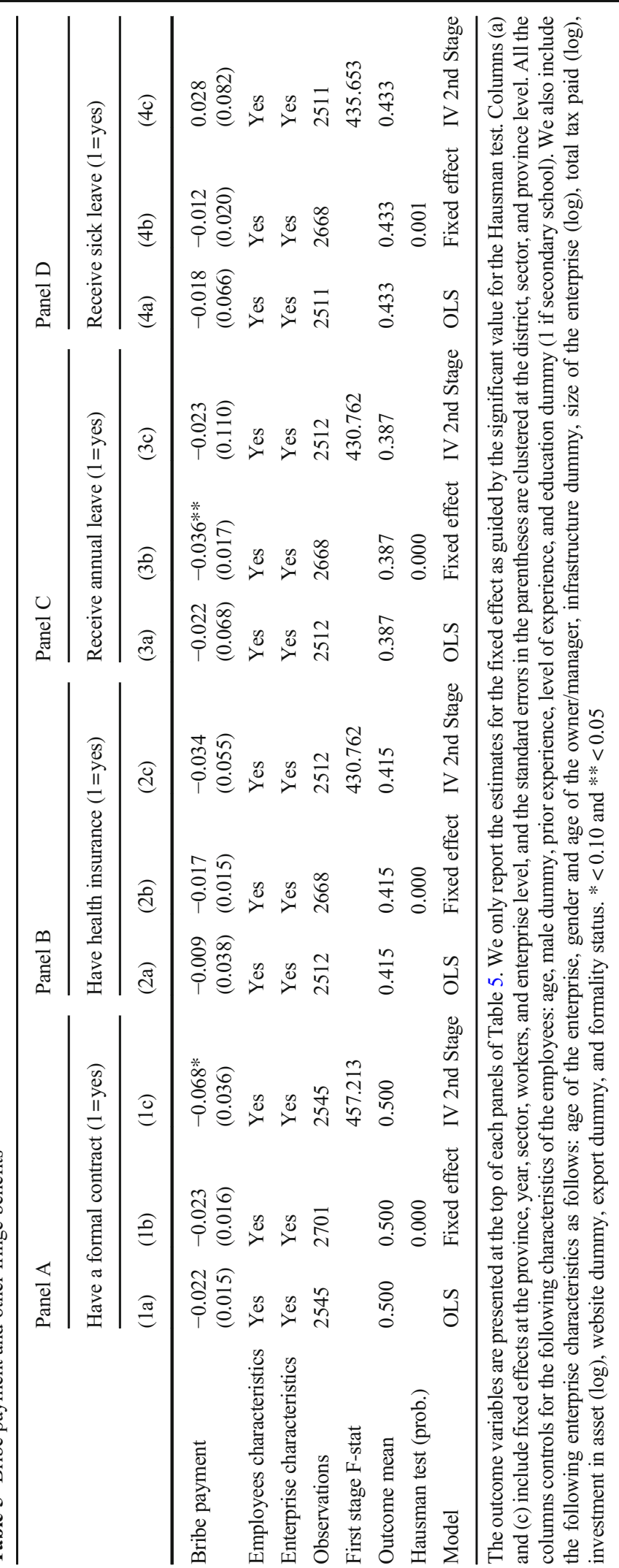


Table 6 Mechanisms of impact of bribe payments on wages

\begin{tabular}{|c|c|c|c|c|}
\hline & \multicolumn{2}{|c|}{ Wages (log) } & \multicolumn{2}{|c|}{ Wages to value added } \\
\hline & {$[1]$} & {$[2]$} & {$[3]$} & {$[4]$} \\
\hline \multicolumn{5}{|l|}{ Panel A: Employee mobility and union membership } \\
\hline Bribe payment $\times$ employee mobility & $\begin{array}{l}0.007 \\
(0.123)\end{array}$ & $\begin{array}{l}-0.003 \\
(0.126)\end{array}$ & $\begin{array}{l}-0.014 \\
(0.017)\end{array}$ & $\begin{array}{l}-0.014 \\
(0.016)\end{array}$ \\
\hline Observations & 2196 & 2343 & 2196 & 2342 \\
\hline Hausman test (prob.) & & 0.050 & & 0.003 \\
\hline Bribe payment $\times$ union membership & $\begin{array}{l}0.325^{* *} \\
(0.129)\end{array}$ & $\begin{array}{l}0.262 * * \\
(0.130)\end{array}$ & $\begin{array}{l}0.0006 * * \\
(0.003)\end{array}$ & $\begin{array}{l}0.0011 * * \\
(0.005)\end{array}$ \\
\hline Observations & 568 & 644 & 568 & 644 \\
\hline Hausman test (prob.) & & 0.000 & & 0.001 \\
\hline \multicolumn{5}{|l|}{ Panel B: Enterprise performance and mobility status } \\
\hline Bribe payment $\times$ performance of the enterprise & $\begin{array}{l}0.029 * * * \\
(0.010)\end{array}$ & $\begin{array}{l}0.025^{* * *} * \\
(0.008)\end{array}$ & $\begin{array}{l}0.000 \\
(0.000)\end{array}$ & $\begin{array}{l}0.0000 \\
(0.0001)\end{array}$ \\
\hline Observations & 1333 & 1472 & 1333 & 1472 \\
\hline Hausman test (prob.) & & 0.002 & & 0.998 \\
\hline Bribe payment $\times$ mobility status & $\begin{array}{l}0.309^{* * *} \\
(0.117)\end{array}$ & $\begin{array}{l}0.341 * * * \\
(0.117)\end{array}$ & $\begin{array}{l}0.035^{* *} \\
(0.015)\end{array}$ & $\begin{array}{l}0.035^{* *} \\
(0.014)\end{array}$ \\
\hline Observations & 2196 & 2343 & 2196 & 2342 \\
\hline Hausman test (prob.) & & 0.040 & & 0.001 \\
\hline \multicolumn{5}{|c|}{ Panel C: Human development effort, employment structure, and regulatory monitoring } \\
\hline Bribe payment $\times$ investment in training workers & $\begin{array}{l}0.053 \\
(0.099)\end{array}$ & $\begin{array}{l}0.112 \\
(0.099)\end{array}$ & $\begin{array}{l}0.033^{* *} \\
(0.013)\end{array}$ & $\begin{array}{l}0.034 * * * \\
(0.013)\end{array}$ \\
\hline Observations & 2196 & 2343 & 2196 & 2342 \\
\hline Hausman test (prob.) & & 0.009 & & 0.001 \\
\hline Bribe payment $\times$ share of casual worker & $\begin{array}{l}1.032 * * * \\
(0.289)\end{array}$ & $\begin{array}{l}0.425^{*} \\
(0.245)\end{array}$ & $\begin{array}{l}0.044 \\
(0.038)\end{array}$ & $\begin{array}{l}0.045 \\
(0.036)\end{array}$ \\
\hline Observations & 2196 & 2343 & 2196 & 2342 \\
\hline Hausman test (prob.) & & 0.085 & & 0.003 \\
\hline Bribe payment $\times$ number of visits by regulatory authority & $\begin{array}{l}0.017 \\
(0.082)\end{array}$ & $\begin{array}{l}0.007 \\
(0.072)\end{array}$ & $\begin{array}{l}0.018 \\
(0.011)\end{array}$ & $\begin{array}{l}0.017 * \\
(0.010)\end{array}$ \\
\hline Observations & 2194 & 2341 & 2194 & 2340 \\
\hline Hausman test (prob.) & & 0.058 & & 0.002 \\
\hline \multicolumn{5}{|l|}{ Panel D: Enterprise formality status } \\
\hline Bribe payment $\times$ enterprise code number & $\begin{array}{l}-0.268^{*} \\
(0.139)\end{array}$ & $\begin{array}{l}-0.516^{* * *} \\
(0.138)\end{array}$ & $\begin{array}{l}-0.131^{* * *} \\
(0.045)\end{array}$ & $\begin{array}{l}-0.129^{* * *} \\
(0.039)\end{array}$ \\
\hline Observations & 988 & 1077 & 988 & 1077 \\
\hline Hausman test (prob.) & & 0.000 & & 0.000 \\
\hline Employees characteristics & Yes & Yes & Yes & Yes \\
\hline Enterprise characteristics & Yes & Yes & Yes & Yes \\
\hline Outcome mean & 7.645 & 7.645 & 0.006 & 0.006 \\
\hline Model & OLS & Fixed effect & OLS & Fixed effect \\
\hline
\end{tabular}

The dependent variables are presented at the top of the columns of Table 6. All the columns (apart from columns for the fixed effect estimations) include fixed effects at the province, year, sector, workers, and enterprise level, and the standard errors are clustered at the district, sector, and province level. All the columns control for the following characteristics of the employees: age, male dummy, prior experience, level of experience, and education dummy ( 1 if secondary school). We also include the following enterprise characteristics as follows: age of the enterprise, gender and age of the owner/manager, infrastructure dummy, size of the enterprise (log), total tax paid (log), investment in asset $(\log )$, website dummy, export dummy, and formality status. $*<0.10 ; * *<0.05 ; * * *<0.01$ 
4.3.3 Human development effort, employment structure, and regulatory monitoring

In panel $\mathrm{C}$, we explore three other potential mechanisms (including the enterprise's human development effort, employment structure, and the extent of regulatory monitoring) to explain the effect of bribe payment on wages. The monetary outcome of workers might be affected by bribe payment depending on human development investment of the enterprise. The standard neoclassical model of human capital investment assumes that labor markets are perfectly competitive and workers are paid according to their marginal product, such that enterprises do not receive any rents from the employment relationship (Pischke 2005). However, in cases where the enterprise directly finances any of the human capital investment, the strategic decision to be made with bribe payment might not be to downwardly adjust wages because of the likelihood of increasing labor mobility from the enterprise.

The effect of bribe payment on workers' monetary outcomes may also be affected by the enterprise's employment structure through inter-temporal budget adjustments, such that enterprises can adjust their wage budget depending on their employment structure. Changes in the intensity of regulatory monitoring are another important mechanism that explains the effect of corruption on enterprise's outcomes (Lavallee and Roubaud 2018).

We compute a dummy variable that takes the value 1 if the enterprise normally trains workers and 0 , otherwise, which is intended to identify enterprises that invest in human capital development efforts. We also consider the enterprise's employment structure as the share of employees who are casual worker, and then the number of visits by the regulatory authority to compute the changes in regulatory intensity. We interact these indicators with bribe payment, and the results are presented in panel $\mathrm{C}$ of Table 6 . The results suggest that a change in regulatory monitoring intensity is not an essential mechanism through which corruption affects workers' wages. However, bribe payment positively affects the ratio of wages to value addition for enterprises with higher investment in human capital development. This could be explained by a higher return to scale of labor despite bribe shock or the enterprise's unwillingness to downwardly adjust their wages with bribe payment because of the likelihood of labor mobility. Regarding the employment structure of an enterprise as an important mechanism that explains the effect of corruption on workers' wages, our results do not show a consistent significant effect.

\subsubsection{Formality status of the enterprise}

Formality status of the enterprise is another mechanism identified in the literature that explains corruption and the extent of compliance with regulations, including labor laws (Rand and Tarp 2012; Meghir et al. 2015). We consider in panel D of Table 6 how the relationship between corruption and workers' wages influenced by the formality status of the enterprise. We consider the formality status of an enterprise as a dummy variable, which takes the value 1 if the enterprise has a formal code number, ${ }^{7}$ and 0 otherwise. We interact this variable with bribe payment, and the result suggests that the adverse effects of bribe payment on the two indicators of workers' monetary compensation are mostly driven by the formality status of the enterprise. This is probably because formalization in a developing country context could exert significant and additional cost on doing business (McKenzie and Sakho 2010), which could adversely affect wages with additional bribe payment.

\subsection{Validation and robustness check}

To validate our identification strategy, we first conduct a falsification test by replicating the key estimations while replacing the main regressor (bribe payment) with a different variable that measures whether the owner/key official of the business expects that bribe payments will increase in the coming years. This variable should be seen as the perception and projection of the owner/key official about the state of "systemic" corruption in their immediate business environment, which could also inform the tendency to self-select into paying a bribe. The OLS estimation results, the fixed effect taking advantage of the panel structure of the data, and the second-stage 2 sls regression are shown in Table 7 in the Appendix.

To be precise, there is a 51-percentage point significant association between the expectation of incremental bribe scenarios in the immediate business environment

\footnotetext{
${ }^{7}$ Authorities in Vietnam are to issue each enterprise a code number showing their formal registration status.
} 
and actual bribe payment by the enterprise. Despite this association, we find no consistent significant and negative effect of such expectation on workers' compensation. Such lack of evidence of an effect suggests that the actual bribe payments are responsible for meaningful changes in workers' compensation, especially the monetary outcome of workers, and not attributed to the owners' expectations about the business environment's conditions concerning bribe payment.

Second, noting the amount spent on bribe payment by the sampled businesses is underreported in the survey ${ }^{8}$; nonetheless, we engage this variable to check whether the relationship with the indicators of workers' compensation is consistent with the results of the earlier estimations in Tables 2, 3, and 5. The estimates in Appendix Table 8 indicate that there is a consistent negative effect of bribe payment on workers' wages and wages to total value addition. However, some variances are observed in the estimates for other non-monetary compensations as far as this new measure of bribe payment is concerned. For example, we find inconsistent significant effect on an employee's probability of having a formal contract and receiving a sick leave.

\section{Conclusion}

In this study, we have examined the effect of bribe payment on workers' wages and other non-monetary entitlements. We have shown that enterprises' bribe payment results in a significant decline in workers' wages, but has no significant effect on other non-monetary compensations, such as having a formal contract, having a health insurance, receiving annual leave, and receiving sick leave. A noteworthy observation from our finding is that this effect occurred noting the significant government interest in addressing corruption in Vietnam, suggesting that there are potential complementary labor market outcomes to policies that address underlying institutional challenges confronting the business environment in developing countries. Therefore, anti-corruption policies are likely to have substantial wage payoffs for workers. We have shown effects for small businesses, but there may be potential for this effect to exist for larger businesses, especially if corruption hurts their performance and growth.

\footnotetext{
${ }^{8}$ The response rate for this variable is $57 \%$ lower compared to the reportage for bribe payment variable.
}

Our analysis regarding the mechanism through which the estimated effect is seen suggests that union membership by employees, enterprises' performance, mobility status of the enterprise, and investment in workers' training are important pathways that explain the relationship. We interpret this result as a possible coping mechanism for employees and enterprises to cushion the negative effect of bribe payment on wages. For example, belonging to a trade union could cushion the adverse impact of corruption on employees' wages through the union's bargaining power. However, the practicality of enterprises improving their performance, increasing their mobility capacity, and investment in workers' training, as strategies to cope with the cost of bribe payment on monetary outcomes of labor, is a paramount concern. Therefore, we support the argument for anti-corruption policies for decent labor outcomes because the coping mechanisms at the enterprise level in the absence of such policy may not be practical for small businesses.

Addressing the cost of formalization in a developing country context is another important factor determining the effect of bribe payment on wages. A qualification to this claim is the negative reinforcing effect that we find for wages of employees in enterprises that engage in bribe payment and are formalized. This suggests that due to the cost of formalization in Vietnam-including fiscal burdens on an enterprise in the form of taxes and general costs of complying with regulatory requirements (Rand and Torm 2012) — additional bribe payments are likely to only adversely affect the monetary outcome of workers.

Acknowledgements The authors are grateful to Professor John Rand of the Development Economics Research Group, University of Copenhagen, for making the raw data available. We are also grateful to the anonymous reviewers for their valuable comments and suggestions that improved the final version of this paper. The first author is grateful to the management and staff of MIASA, University of Ghana, for the working space and goodwill extended to him in the period of the COVID 19 lockdown, during which this research was completed. We take responsibility for all errors.

Data availability The data for this study is available upon request.

\section{Declarations}

Conflict of interest The authors declare no competing interests. 


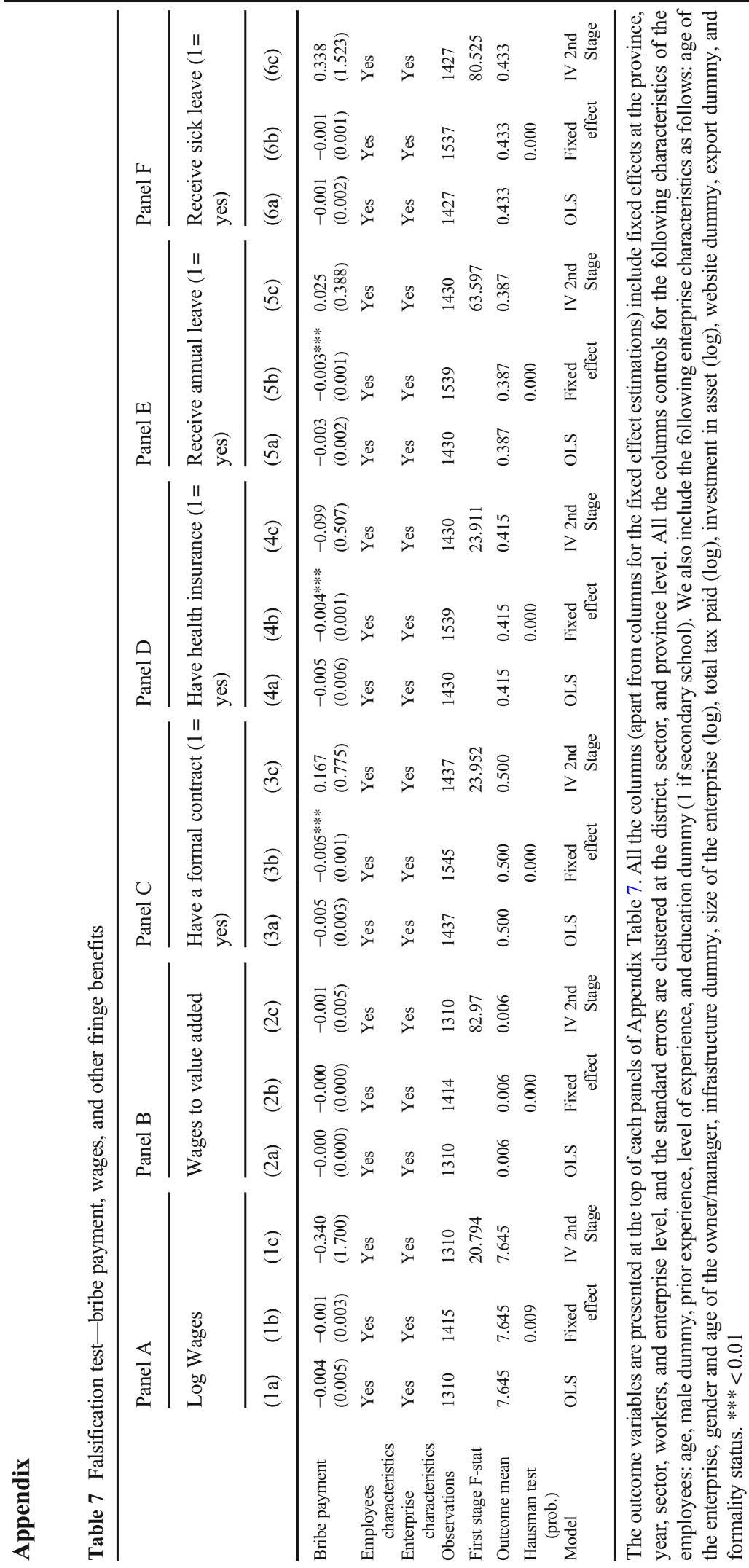




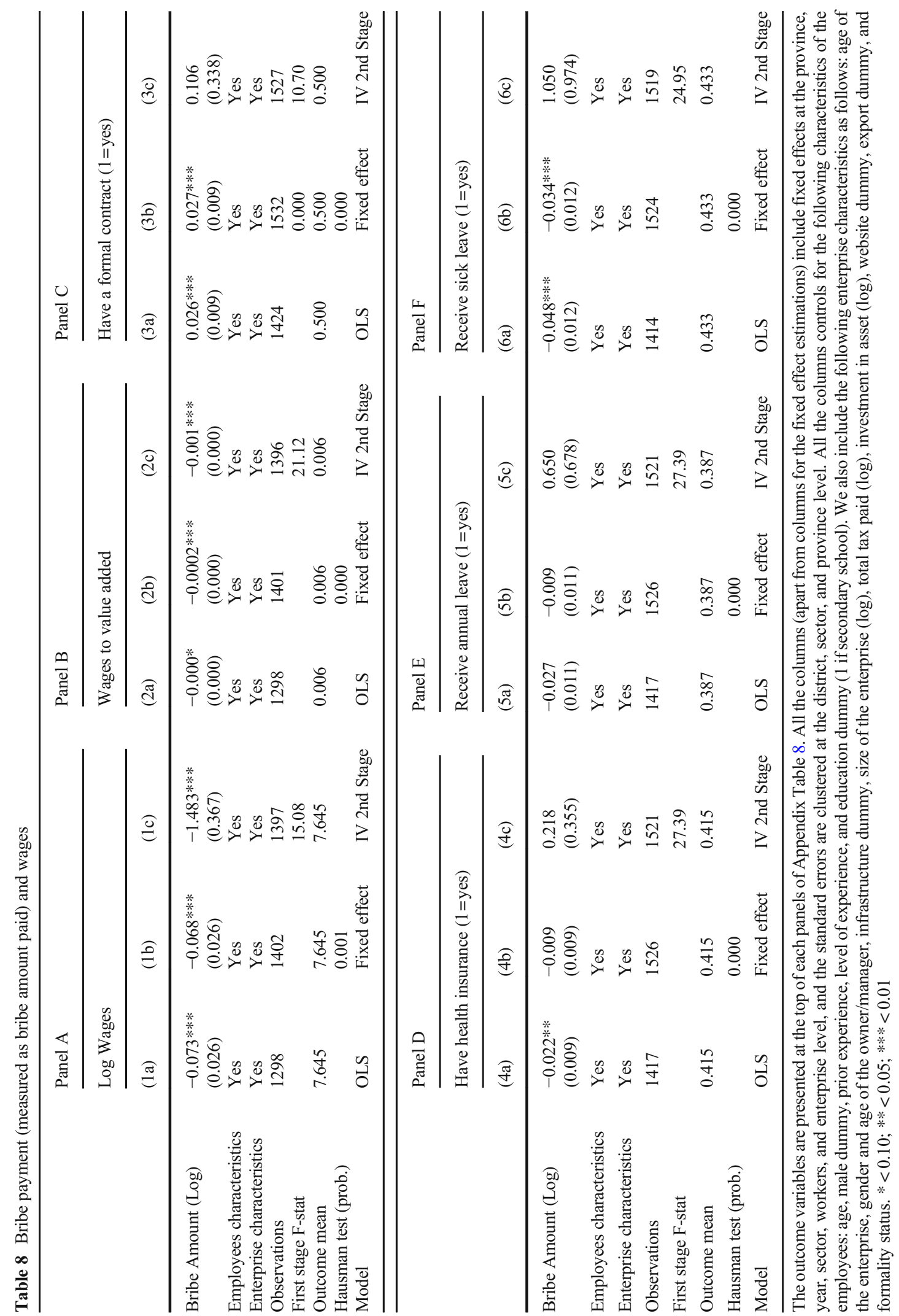




\section{References}

Angrist, J. D. (2001). Estimation of limited-dependent variable models with dummy endogenous regressors: Simple strategies for empirical practice. Journal of Business and Economic Statistics, 19(1), 2-16. https://doi.org/10.1198 /07350010152472571.

Bai, J., Jayachandran, S., Malesky, E. J., \& Olken, B. A. (2017). Firm growth and corruption: Empirical evidence from Vietnam. The Economic Journal, 129, 651-677. https://doi. org/10.1111/ECOJ.12560.

Banerjee, A. V. (1997). A theory of mis-governance. Quarterly Journal of Economics, 112, 1289-1332. https://doi. org/10.1162/003355300555484.

Campbell, B. A., Ganco, M., Franco, A. M., \& Agarwal, R. (2012). Who leaves, where to, and why worry? Employee mobility, entrepreneurship and effects on source firm performance. Strategic Management Journal, 33(1), 65-87. https://doi.org/10.1002/smj.943.

Chen, F. (2000). Subsistence Crises, Managerial Corruption and Labour Protests in China. The China Journal, 44, 41-63. https://doi.org/10.2307/2667476.

Cole, S., \& Tran, A. (2011). Bribes for Sales: Evidence from the Second Set of Books. American Economic Association. https://doi.org/10.2139/SSRN.1986930.

Cooray, A., \& Dzhumashev, R. (2018). The effect of corruption on labour market outcomes. Economic Modeling, 74, 207-218. https://doi.org/10.1016/j.econmod.2018.05.015.

Coyne, K., Coyne, S.T., and Coyne, E.J., (2010), When you've got to cut costs - Now, Harvard Business Review, https://hbr. org/2010/05/when-youve-got-to-cut-costs-now

Dutta, N., \& Sobel, R. (2016). Does corruption ever help entrepreneurship? Small Business Economics, 47, 179-199. https://doi.org/10.1007/s11187-016-9728-7.

Fisman, R., \& Svensson, J. (2007). Are corruption and taxation really harmful to growth? Firm level evidence. Journal of Development Economics, 83(1), 63-75. https://doi. org/10.1016/j.jdeveco.2005.09.009.

International Labour Organization (2020), Decent work and the 2030 Agenda for sustainable development, Retrieved from https://www.ilo.org/global/topics/sdg-2030/lang\%2D\%2 Den/index.htm

Lavallee, E., \& Roubaud, F. (2018). Corruption in the informal Sector: Evidence from West Africa. The Journal of Development Studies. https://doi.org/10.1080 /00220388.2018.1438597.

Liu, A. Y. C. (2004). Gender wage gap in Vietnam: 1993 to 1998. Journal of Comparative Economics, 32(3), 586-596. https://doi.org/10.1016/j.jce.2004.04.004.

Martini, M., (2012), Overview of corruption and anti-corruption in Vietnam, Transparency International, https:/www.u4. no/publications/overview-of-corruption-and-anti-corruptionin-vietnam.pdf

Mendez, F., \& Sepulveda, F. (2006). Corruption, growth and political regimes: Cross country evidence. European Journal of Political Economy, 22(1), 82-98.

McKenzie, D. (2017). Identifying and spurring high-growth entrepreneurship: Experimental evidence from a business plan competition. American Economic Review, 107(8), 22782307. https://doi.org/10.1257/aer.20151404.
McKenzie, D., \& Sakho, Y. S. (2010). Does it pay firms to register for taxes? The impact of formality on firm profitability. Journal of Development Economics, 91(1), 15-24. https://doi.org/10.1016/j.jdeveco.2009.02.003.

Meghir, C., Narita, R., \& Robin, J. (2015). Informality in developing countries. American Economic Review, 105(4), 15091546. https://doi.org/10.1257/aer.20121110.

Mendoza, R. U., Lim, R. A., \& Ong Lopez, A. (2015). Grease or sand in the wheels of commerce? Firm-level evidence on corruption and SMEs. Journal of International Development, 27(4), 415-439.

O'Toole, C. M., \& Tarp, F. (2014). Corruption and the efficiency of capital investment in developing countries. Journal of International Development, 26(5), 567-597. https://doi. org/10.1002/jid.2997.

Paunov, C. (2016). Corruption's asymmetric impacts on firm innovation. Journal of Development Economics, 118, 216 231. https://doi.org/10.1016/j.jdeveco.2015.07.006.

PCI (2020), PCI Data - Methodology, Retrieved from https://pcivietnam.vn/en/about/pci-methodology.html

Pischke, J. (2005). Labor market institutions, wages, and investment: Review and implications. CESifo Economic Studies, 51(1), 47-75. https://doi.org/10.1093/cesifo/51.1.47.

Rand, J., \& Tarp, F. (2007). Characteristics of the vietnamese business environment: Evidence from a survey in 2005. Hanoi, Vietnam: Central Institute of Economic Management (CIEM).

Rand, J., \& Tarp, F. (2012). Firm-level corruption in Vietnam. Economic Development and Cultural Change, 60(3), 571595. https://doi.org/10.1086/664022.

Rand, J., \& Torm, N. (2012). The benefits of formalization: Evidence from Vietnamese manufacturing SMEs. World Development, 40(5), 983-998. https://doi.org/10.1016/j. worlddev.2011.09.004.

Schneider, F., (2015), does corruption promote emigration? IZA World of Labour, 192, DOI: https://doi.org/10.15185 /izawol.192

Șeker, M., \& Yang, J. S. (2014). Bribery solicitations and firm performance in the Latin America and Caribbean region. Journal of Comparative Economics, 42, 246-264. https://doi.org/10.1016/j.jce.2013.05.004.

Sorensen, H. E. (2011). Resource specialization, customer orientation, and firm performance: An empirical investigation of valuable resources. Journal of Strategic Marketing, 19(4), 395-412. https://doi.org/10.1080/0965254X.2011.586718.

Sylwester, K. (2019). Extortion or cost-reduction: Why do firms pay bribes? Journal of Applied Economics, 22(1), 85-101. https://doi.org/10.1080/15140326.2018.1526876.

Tran, T. B., Grafton, R. Q., \& Kompas, T. (2009). Institutions matter: The case of Vietnam. The Journal of SocioEconomics, 38(1), 1-12. https://doi.org/10.1016/j. socec.2008.05.012.

Transparency International (2020), Vietnam: CPI 2019 Score is up but Corruption remains Serious, Retrieved from https://towardstransparency.vn/en/vietnam-cpi-2019-scoreis-up-but-corruption-remains-serious/

Trifkovic, N. (2017). Spillover effects of international standards: Working conditions in the Vietnamese SMEs. World Development, 97, 79-101. https://doi.org/10.1016/j. worlddev.2017.03.040. 
Van Rijckeghem, C., and Weder, B., (1997), Corruption and the Rate of Temptation: Do Low Wages in the Civil Service Cause Corruption? International Monetary Fund Paper, WP/97/73, https://www.imf.org/external/pubs/ft/wp/wp9773.pdf

Verdu, F. M., \& Tierno, N. R. (2019). Clustering and innovation: Firm-level strategizing and policy. Entrepreneurship and Regional Development, 31(1-2), 1-6. https://doi. org/10.1080/08985626.2018.1537143.

Vial, V., \& Hanoteau, J. (2010). Corruption, manufacturing plant growth, and the Asian paradox: Indonesian evidence. World Development, 38(5), 693-705. https://doi.org/10.1016/j. worlddev.2009.11.022.

Weaver, J. (2016). Jobs for Sale: Corruption and misallocation in hiring. Yale University mimeo.
Williams, C. C., \& Kedir, A. M. (2016). The impacts of corruption on firm performance: Some lessons from 40 African countries. Journal of Developmental Entrepreneurship, 21(04), 1650022. https://doi.org/10.1142/S1084946716500229.

Williams, C., Martinez-Perez, A., \& Kedir, A. (2017). Informal entrepreneurship in developing economies: The impacts of starting up unregistered on firm performance. Entrepreneurship Theory and Practice, 41(5), 773-799. https://doi.org/10.1111/etap.12238.

Publisher's note Springer Nature remains neutral with regard to jurisdictional claims in published maps and institutional affiliations. 